\title{
Implications of Robotic Walkway Cleaning for Hoof Disorders in Dairy Cattle
}

\author{
R.L. Doerfler*, R. Martin**, H. Bernhardt* \\ * (Agricultural Systems Engineering, TUM School of Life Sciences Weihenstephan, Technical University of \\ Munich, Freising, Germany) \\ **(Clinic for Ruminants with Ambulatory and Herd Health Services, LMU Munich, Oberschleissheim, \\ Germany)
}

\begin{abstract}
Infectious hoof disorders are a serious challenge for dairy production since they cause pain and discomfort in cows and can compromise the competitiveness of dairy farming. Robot scrapers are capable of frequently removing liquid manure from slatted floors and can contribute to improved hygiene of walkways. The aim of this study was to observe the implications of the robotic cleaning of walking areas for infectious hoof disorders in dairy cattle. A large herd ranging from 1,247 to 1,328 Holstein Friesian cows was monitored in two six-month periods in 2012 and in 2013. All animals were housed in a cubicle housing system with slatted floors in which walkways were cleaned using robot scrapers in 2013 but not in 2012. Statistical analysis was carried out with either the Chi-square test or the Fisher's exact test in R. Results indicated that the presence of infectious hoof disorders declined after robot scrapers were used for the cleaning of walkways. While in the first investigation period 648 animals suffered from infectious hoof diseases, in the second period only 340 animals were affected. This study stresses the significance of environmental hygiene to improve hoof health in dairy cattle.
\end{abstract}

Keywords: hoof disease, robot scraper, dairy cattle, hygiene, walkway

\section{INTRODUCTION}

Infectious hoof diseases are multifactorial in nature. They cause pain and discomfort in cows [1], and therefore, have crucial implications for animal welfare [2]. Reduced welfare is intrinsically connected to reduced production and fertility. As a result, the economic viability of affected herds is compro mised.

Poor environmental hygiene is an important predisposing factor for the origin of infectious hoof disorders [3,4,5]. In particular, prolonged exposure of the hoof skin and horn to liquid manure, and comparatively anaerobic conditions are decisive factors for the damage of the skin and horn, resulting in the transmission of infectious agents onto the bovine feet and in infection of the dig its $[6,7]$.

Besides the preventive and curative treatment of affected animals, measures directed at predisposing factors in the environment are vital to control infectious hoof diseases [8]. The maintenance of the robustness and resistance of the feet skin and horn should be given priority to avoid erosions. Dry and clean walkways are crucial to prevent cutaneous maceration and infectious hoof disorders [9,10]. Environmental hygiene can be improved by traditional manure scrapers or by robot scrapers. The accumulator-operated robots autonomously push the manure down through the slats of walkways and cross-overs.
Somers et al. [11,12] in their study indicated that the risk for infectious hoof disorders in dairy cows decreased, when walkways were cleaned with mechanical manure scrapers. Several studies found that short cleaning intervals considerably reduce manure on walkways and improve the cleanliness of dairy cattle and the housing environment $[13,14,15]$. This is inconsistent with the observations of Cramer et al. [16] indicating that there was a negative relationship between the frequency of alley scraping and the prevalence of digital dermatitis. A previous study addressed hoof trauma caused by manure removing equipment that may harm skin and horn barriers of the bovine feet [10].

The majority of studies on hoof disorders in dairy cows focused on the identification of predisposing factors, but few looked upon the impact of technical measures to improve environmental hygiene and hoof health. This study examined the implications of robot scraper use for the cleaning of walkways on the incidence of infectious digital disorders and associations with parity and stage of lactation. 


\section{MATERIAL AND METHODS}

2.1 Study design, herd, and housing

In this study data, representing the incidences of hoof disorders in a dairy herd consisting of between 1.247 and 1.328 lactating Holstein Friesian cows over the study periods, were analyzed. These data were documented during regular hoof trimmings from February to July in 2012 and from February to July in 2013. In the second period the walkways in the barn were cleaned by five robot scrapers more than two times a day, whereas in the first period the walkways were cleaned using a tractor two times a day.

All cows were housed in a cubicle accommodation on slatted floors that was divided into 16 compartments. The compartments were arranged on both sides of the alley to the rotary milking parlor. Each compartment was equipped with three parallel rows of cubicles, walkways with concrete slatted floors and the feeding fence. In the course of lactation the animals were moved through these 16 compartments based on their level of performance. The walking area of each compartment was about $230 \mathrm{~m}^{2}$. As a result, five robot scrapers cleaned the total walking area of about $3,650 \mathrm{~m}^{2}$. The cleaning time of each robot took approximately 15 hours a day, whereas the charging time took approximately 9 hours a day. The scraping events lasting 30 to $40 \mathrm{~min}$ started every full hour.

The ad libitum total mixed ration was fed via a belt feeder. Grazing was available for dry cows and heifers during the vegetation period. The cows calved throughout the year and were milked twice daily in a rotary milking parlor with 40 places. They produced an average of about $9,200 \mathrm{~kg}$ milk per year. Neither the herd management and feeding nor the housing environment was altered during the study.

\subsection{Data recor ding}

Professional hoof trimmers performed the examination of the hooves and completed the documentation of digital diseases in the herd management program (dsp agrosoft, Germany; HERDE) at least three times per year for each cow. Individual diagnoses for digital dermatitis (DD), interdigital dermatitis (DID), and heel erosion (HE) were entered into a touchpad PC during the inspection of the cows in the hoof trimming chute. Incidences were documented but not analyzed separately for the different hooves and for inside and outside hooves. Cows suffering from hoof disorder were treated immediately.

The records for each individual cow included the date of the first and, where appropriate, further diagnosis of the hoof disorder, parity, days in milk (DIM), and milk yield based on the monthly records of the control milking. The mean parity \pm
SD of animals diagnosed with DD, DID, and HE was $2.37 \pm 1.36,2.61 \pm 1.54$, and $2.23 \pm 1.21$ in 2012 and $2.70 \pm 1.44,2.86 \pm 1.63$, and $2.82 \pm 1.83$ in 2013 . The mean DIM \pm SD of sick cows was $186.60 \pm 132.30,134.50 \pm 119.80$, and $231.60 \pm 127.90$ in 2012 and $162.60 \pm 117.90,146.40 \pm 124.10$, and $188.50 \pm 107.00$ in 2013 .

A small number of cows fell ill two times or, in very few cases, three times within one investigation period (Table 1). The number of mu ltiple illnesses in DD was 40 and 21, in DID 31 and 11, and in HE 2 and 0 in 2012 and 2013, respectively.

Table 1. Nu mber (n) and proportion (\%) of mu ltiple illnesses in 2012 and 2013 for dig ital dermatitis (DD), interdigital dermatit is (DID), and heel erosion (HE).

\begin{tabular}{|l|l|l|l|}
\hline & Year & $\begin{array}{l}\text { No. of multiple } \\
\text { illnesses (n) }\end{array}$ & $\begin{array}{l}\text { Prop. of multiple } \\
\text { illnesses (\%) }\end{array}$ \\
\hline DD & 2012 & 40 & 11.7 \\
\hline & 2013 & 21 & 11.1 \\
\hline DID & 2012 & 31 & 13.2 \\
\hline & 2013 & 11 & 9.4 \\
\hline HE & 2012 & 2 & 2.9 \\
\hline & 2013 & 0 & 0.0 \\
\hline Total & 2012 & 73 & 11.3 \\
\hline & 2013 & 32 & 9.4 \\
\hline
\end{tabular}

\subsection{Data management and analysis}

All data were extracted from the herd management program and transferred to $\mathrm{R}$ for data analysis. The incidences of infectious hoof disorders were analyzed for differences between the first and second investigation periods; a total of 988 records.

Differences in parity and DIM of affected animals were analyzed between both investigation periods. Parity was categorized in $1,2,3,4,5$, and $\geq 6$, DIM in 0 to 30,31 to 60,61 to 90,91 to 120 , 121 to 150,151 to 180,181 to 210,211 to 240,241 to 270,271 to 300,301 to 330,331 to 360 , and $>361$.

Statistical analysis was carried out using the Chi-square test in $\mathrm{R}$ ( $\mathrm{R}$ version 3.3.0). Whenever there were violated assumptions of the Chi-square test in individual instances, the Fisher's exact test was used. The level of significance was $\mathrm{P}<0.05$.

\subsection{Incidences}

\section{RESULTS}

Data analysis showed that the use of robot scrapers for the cleaning of walkways resulted in reduced incidences of DD, DID, and $\mathrm{HE}$ in the second investigation period compared to the first period (Table 2). The number of animals diagnosed with DD declined from 343 cases in 2012 to 190 cases in $2013(\mathrm{P}<0.001)$. 
Table 2. Nu mber (n) and proportion (\%) of incidences of digital dermatit is (DD), interdigital dermatitis (DID), and heel erosion (HE) in 2012 and 2013, and P-values.

\begin{tabular}{|l|l|l|l|l|}
\hline & Year & $\begin{array}{l}\text { No. of } \\
\text { incidences } \\
(\mathrm{n})\end{array}$ & $\begin{array}{l}\text { Prop. of } \\
\text { incidences } \\
(\%)\end{array}$ & P-value \\
\hline DD & 2012 & 343 & 52.9 & \\
\hline & 2013 & 190 & 55.9 & $\mathrm{P}<0.001^{1}$ \\
\hline DID & 2012 & 235 & 36.3 & \\
\hline & 2013 & 117 & 34.4 & $\mathrm{P}=0.003^{1}$ \\
\hline HE & 2012 & 70 & 10.8 & \\
\hline & 2013 & 33 & 9.7 & $\mathrm{P}<0.001^{2}$ \\
\hline Total & 2012 & 648 & 100.0 & \\
\hline & 2013 & 340 & 100.0 & \\
\hline
\end{tabular}

1 Based on Chi-square test

${ }^{2}$ Based on Fisher's exact test

Incidences of HE decreased from 70 cases to 33 cases between both investigation periods $(\mathrm{P}<0.001)$, and incidences of DID were recorded in 235 cows and 117 cows $(\mathrm{P}=0.003)$, respectively. Thus, DD occurred most frequently in the dairy herd, while the presence of DID and HE was less and least frequent, respectively. In total 648 animals were diagnosed with at least one infectious hoof disease in 2012 compared to 340 animals in 2013.

The proportion of incidences in both investigation periods varied only within a small range. The proportion of DD rose from $52.9 \%$ to $55.9 \%$ in the periods considered. In contrast, the proportion of DID declined from $36.3 \%$ to $34.4 \%$ and that of $\mathrm{HE}$ decreased from $10.8 \%$ to $9.7 \%$ between the first and the second investigation periods.

Table 3 demonstrates that the total number of incidences of all infectious hoof disorders investigated was fewer in all months of 2013 than of 2012.

Table 3. Monthly distribution of the number of lactating cows (n), and the number (n) and proportion $(\%)$ of incidences of infectious hoof disorders in 2012 and 2013.

\begin{tabular}{|l|l|l|l|}
\hline $\begin{array}{l}\text { Month/ } \\
\text { Year }\end{array}$ & $\begin{array}{l}\text { No. of } \\
\text { lact. } \\
\text { cows (n) }\end{array}$ & $\begin{array}{l}\text { No. of } \\
\text { incidences } \\
\text { (n) }\end{array}$ & $\begin{array}{l}\text { Prop. of } \\
\text { incidences } \\
(\%)\end{array}$ \\
\hline February & & & \\
\hline 2012 & 1303 & 61 & 4.7 \\
\hline 2013 & 1315 & 53 & 4.0 \\
\hline March & & & \\
\hline 2012 & 1264 & 94 & 7.4 \\
\hline 2013 & 1328 & 79 & 6.0 \\
\hline April & & & \\
\hline 2012 & 1250 & 117 & 9.4 \\
\hline 2013 & 1262 & 84 & 6.7 \\
\hline May & & & \\
\hline 2012 & 1257 & 124 & 9.9 \\
\hline 2013 & 1269 & 59 & 4.7 \\
\hline June & & & \\
\hline
\end{tabular}

\begin{tabular}{|l|l|l|l|}
\hline 2012 & 1266 & 121 & 9.6 \\
\hline 2013 & 1288 & 16 & 1.2 \\
\hline July & & & \\
\hline 2012 & 1247 & 131 & 10.5 \\
\hline 2013 & 1271 & 49 & 3.9 \\
\hline
\end{tabular}

In 2012 the incidences of disorders continually increased from 61 cases in February to 131 cases in July. In February and March the observed incidences were markedly fewer than the incidences from April onwards. In 2013 the incidences of infectious hoof diseases initially increased from 53 cases in February to 84 cases in April, then declined from April to June to a minimum of 16 cases and finally slightly rose to 49 cases from June to July. It is further worth mentioning that in February 2013 more animals were affected with DD than in February of the preceding year. Thus, the incidences of DD in dairy cows initially increased when cleaning the walkways with robot scrapers. In the following months of the second investigation period, the incidences declined when compared to the same months of the first period. Similarly, the number of animals diagnosed with HE was higher in February and March 2013 than in the same months of the previous year.

\subsection{Parity}

As illustrated in Table 4, the parity of cows suffering from at least one infectious hoof disease differed between both investigation periods $(\mathrm{P}<0.001)$. In primiparous animals the alteration was characterized by a sharp decline in the incidences of infectious hoof disorders from 221 cases in 2012 to 77 cases in 2013. Similarly, the number of sick cows from the second to the fifth parity declined between the first and second investigation periods. In 2012 $155,119,89$, and 51 cows were in the second, third, fourth and fifth parity, respectively, while in 2013 there were $77,102,63,50$, and 23 cows.

Table 4. Nu mber (n) and proportion (\%) of incidences of infectious hoof disorders according to parity of cows in 2012 and 2013.

\begin{tabular}{|l|l|l|l|l|l|}
\hline Parity & \multicolumn{2}{|l|}{$\begin{array}{l}\text { Number of } \\
\text { incidences (n) }\end{array}$} & \multicolumn{2}{l|}{$\begin{array}{l}\text { Proportion of } \\
\text { incidences (\%) }\end{array}$} & P-value \\
\cline { 2 - 6 } & 2012 & 2013 & 2012 & 2013 & \\
\hline 1 & 221 & 77 & 34.1 & 22.6 & \\
\hline 2 & 155 & 102 & 23.9 & 30.0 & \\
\hline 3 & 119 & 63 & 18.4 & 18.5 & \\
\hline 4 & 89 & 50 & 13.7 & 14.7 & \\
\hline 5 & 51 & 25 & 7.9 & 7.4 & \\
\hline$\geq 6$ & 13 & 23 & 2.0 & 6.8 & \\
\hline Total & 648 & 340 & 100.0 & 100.0 & $\mathrm{P}<0.001^{1}$ \\
\hline
\end{tabular}

${ }^{1}$ Based on Chi-square test

It is striking that in 2013 the number of incidences of infectious hoof diseases in cows in the second parity exceeds the number of incidences in 
cows in the first parity. The number of cows suffering from infectious hoof disorder that were in the sixth parity or above increased from 13 to 23 cases between both investigation periods. Thus, in the oldest cows of the herd there was no improvement in hoof health compared to cows in other parities.

Moreover, the proportion of the incidences of hoof disorder in different parities varied between both investigation periods. In 2012 the highest proportion $(34.1 \%$ ) was in parity 1 , whereas in 2013 it was in parity $2(30.0 \%)$. The proportion of incidences of hoof disorder in cows from parity 3 to 5 was almost equal in both investigation periods, whereas in cows in parity $\geq 6$ the proportion was higher in $2013(6.8 \%)$ than in $2012(2.0 \%)$.

\subsection{Stage of lactation}

Data further indicated differences $(\mathrm{P}<0.001)$ in the stage of lactation of affected cows between both investigation periods (Table 5). In 2012 the incidences of infectious hoof disorders were by far the highest in cows between 0 and 30 DIM. Other peaks occurred in cows between 121 and 150, 151 and 180, 241 and 270, 171 and 300 DIM, and in cows > 361 DIM. In 2013 the incidences of infectious hoof diseases in cows between 0 and 30 DIM declined compared to 2012. Conversely, the incidences of infectious hoof diseases in cows between 31 and 60 DIM increased between 2012 and 2013. A ltogether, the number of incidences over the entire lactation period showed an undulating development. This wave-like development was not as pronounced in 2013 as in 2012 .

Table 5 further showed that in cows between 31 and 60, 61 and 90, and 91 and 120 DIM as well as in cows between 211 and 240, 241 and 270, 271 and 300, and 301 and 330 DIM the proportion of incidences of infectious hoof diseases in 2013 was higher compared to 2012. There was a marked increase from $8.0 \%$ to $18.5 \%$ in cows between 31 and 60 DIM. Conversely, the proportion of incidences of infectious hoof diseases in cows between 121 and 150, 151 and 180, 181 and 210, and >361 DIM was fewer in 2013 than in 2012.

\section{DISCUSSION}

\subsection{Incidences}

It is very likely that the automated cleaning of walkways caused the marked drop in the number of incidences of infectious hoof disorders in the second investigation period. Numerous studies provided evidence that deficient hygiene through accumulation of liquid manure in the housing environment of animals led to maceration and damage of hooves, and made them vulnerable to pathogenic agents, whereas dry conditions on walkways maintain the robustness and intactness of hooves [5,6,17]. Hultgren and Bergsten [18] attributed the variation for heel-horn erosion between herds to different hygienic conditions of walking and lying areas. The results of this study are in agreement with Somers et al. [11,12] and Magnusson et al. [19] revealing that the cleaning of walkways with traditional, mechanical manure scrapers reduces the risk for infectious hoof disorders in dairy cattle. Several studies found that short cleaning intervals considerably reduce manure on walkways and improve the cleanliness of dairy cattle and the housing environment [13,14,15]. Similarly, the short cleaning intervals of the robot scrapers prevented the aggregation of liquid manure on walkways and improved environ mental hygiene.

Table 5. Nu mber (n) and proportion (\%) of incidences of infectious hoof disorders by stage of lactation of cows in 2012 and 2013.

\begin{tabular}{|c|c|c|c|c|c|}
\hline \multirow[t]{2}{*}{$\begin{array}{l}\text { Days in } \\
\text { milk } \\
\text { (DIM) }\end{array}$} & \multicolumn{2}{|c|}{$\begin{array}{l}\text { Number of } \\
\text { incidences } \\
\text { (n) }\end{array}$} & \multicolumn{2}{|c|}{$\begin{array}{l}\text { Proportion of } \\
\text { incidences } \\
(\%)\end{array}$} & \multirow[t]{2}{*}{ P-value } \\
\hline & 2012 & 2013 & 2012 & 2013 & \\
\hline $0-30$ & 131 & 47 & 20.2 & 13.8 & \\
\hline $31-60$ & 52 & 63 & 8.0 & 18.5 & \\
\hline $61-90$ & 25 & 20 & 3.9 & 5.9 & \\
\hline $91-120$ & 45 & 26 & 6.9 & 7.6 & \\
\hline 121-150 & 68 & 22 & 10.5 & 6.5 & \\
\hline $151-180$ & 60 & 23 & 9.3 & 6.8 & \\
\hline $181-210$ & 35 & 13 & 5.4 & 3.8 & \\
\hline $211-240$ & 30 & 22 & 4.6 & 6.5 & \\
\hline $241-270$ & 44 & 29 & 6.8 & 8.5 & \\
\hline $271-300$ & 47 & 28 & 7.3 & 8.2 & \\
\hline $301-330$ & 35 & 19 & 5.4 & 5.6 & \\
\hline $331-360$ & 20 & 15 & 3.1 & 4.4 & \\
\hline$>361$ & 57 & 14 & 8.8 & 4.1 & \\
\hline Total & 648 & 340 & 100.0 & 100.0 & $\mathrm{P}<0.001^{\mathrm{I}}$ \\
\hline
\end{tabular}

Based on Chi-square test

The relationship between lameness in dairy cows and the decrease of milk production [20,21,22] and reproductive performance $[23,24,25]$ was verified in several studies. Fewer incidences of infectious hoof disorders in the dairy herd reduce the adverse effects on the productive performance and improve the well-being of individual cows.

\subsection{Parity}

It is widely accepted that hoof diseases and lameness are more prevalent in multiparous than in primiparous cows $[4,20,26]$ and the frequency of hoof disorders increases with growing parity $[27,28,29]$. In this study the larger number and proportion of sick animals in parity 6 and above in 2013 compared to 2012 may have resulted from decreased culling rates. Because of the better health status, fewer cows were culled in each parity and more cows grew older in 2013 than in 2012. This hypothesis is supported by a previous study 
supposing that more intense culling of ill primiparous cows could have changed the cows' incidences of digital disorders in parity 2 to 9 [27].

However, previous studies also suggested that the huge physiological, environmental and social changes primiparous cows are faced with at first calving led to higher susceptibility to pathogens $[27,30]$. This can explain the larger number and proportion of affected primiparous cows in the first investigation period of the present study compared to the second investigation period.

A possible explanation for the shift of the maximum incidence of infectious hoof disorders from the first to the second parity in the second investigation period is that the development of diseases decelerated owing to improved environmental hygiene and substantially reduced infection pressure. Moreover, it is likely that cows that had been fallen ill in 2012 were more susceptible to hoof diseases in 2013.

\subsection{Stage of lactation}

The highest incidences of digital disorders in cows between 0 and 30 DIM as found in the present study in 2012 are consistent with earlier findings [20,26,31]. Preceding reports provided evidence to suggest that the large number of incidences of infectious digital disorders in cows between 0 and 30 DIM was caused by the farreaching physiological and environmental alterations in the late pregnancy and early lactation [20,32]. Histological alterations in hooves that occur at calving time [33] may also have contributed to the outbreak of hoof disease.

In 2013 under cleaner environmental conditions resulting from robot scraper operation, the highest incidences occurred not in cows between 0 and 30 DIM but at the onset of peak lactation in cows between 31 and 60 DIM. Some previous studies also confirmed that in cows at peak lactation incidences of digital disorders are highest due to intense metabolic stress [31,34].

\section{CONCLUSIONS}

This study demonstrated that the incidences of infectious hoof disorders in cows decreased when walkways were cleaned by robot scrapers. Since infectious hoof disorders are frequently associated with severe pain, the improvement of hoof health positively affects animal welfare and production. The research design using two investigation periods at different time intervals implies the possibility of disregarding influencing factors and limits the validity of the results. Further research can contribute to additional knowledge in this field.

\section{ACKNOWLEDGEMENTS}

The authors wish to thank the staff of the participating dairy farm for their contribution to this study. We are grateful to Annette Reimann for data provision and to Christina Koestler for data collection.

\section{REFERENCES}

[1]. H.R. Whay, A.E. Waterman, and A.J.F. Webster, Associations between locomotion, claw lesions and nociceptive threshold in dairy heifers during the peri-partum period, Veterinary Journal, 154, 1997, 155-161.

[2]. J. Webster. Animal welfare: limping towards Eden (Blackwell, Oxford, UK, 2005).

[3]. N.B. Cook, K.V. Nordlund, and G.R. Oetzel. Environmental influences on claw horn lesions associated with laminitis and subacute ruminal acidosis in dairy cows, Journal of Dairy Science, 87, 2004, E36E46.

[4]. A.M. Sogstad, T. Fjeldaas, and O. Osteras, Lameness and claw lesions of the Norwegian red dairy cattle housed in free stalls in relation to environment, parity and stage of lactation, Acta Veterinaria Scaninavica, 46, 2005, 203-217.

[5]. S. Popescu, R. Stefan, E.A. Diugan, C. Borda, M. Spinu, and C. Sandru, Relationship between barn hygiene and lameness prevalence in thirty-five Transylvanian dairy farms, Veterinary Medicine, 67, 2010, 222-228.

[6]. T.F. Borderas, B. Pawluczuk, A.M. de Passillé, and J. Rushen, Claw hardness of dairy cows: relationship to water content and claw lesions. Journal of Dairy Science, 7, 2004, 2085-2093.

[7]. A. Gomez, N.B. Cook, N.D. Bernardoni, J. Rieman, A.F. Dusick, R. Hartshorn, M.T. Socha, D.H. Read, and D. Döpfer, An experimental infection model to induce digital dermatitis infection in cattle, Journal of Dairy Science, 95, 2012, 1821-1830.

[8]. R.A. Laven, and D.N. Logue, Treatment strategies for digital dermatitis for the UK, Veterinary Journal, 171, 2006, 79-88.

[9]. K. Nuss, Footbaths: The solution to digital dermatitis?, Veterinary Journal, 171, 2006, 11-13.

[10]. K. Sarjokari, K.O. Kaustell, T. Hurme, T. Kivinen, O.A.T. Peltoniemi, H. Saloniemi, P.J. Rajala-Schultz, Prevalence and risk factors for lameness in insulated free stall barns in Finland, Livestock Science, 156, 2013, 44-52. 
[11]. J.G.C.J. Somers, W.G.P. Schouten, K. Frankena, E.N. Noordhuizen-Stassen, and J.H.M. Metz, Risk factors for dermatit is digitalis in dairy cows kept in cubicle houses in The Netherlands, Preventive Veterinary Medicine, 71, 2005a, 11-21.

[12]. J.G.C.J. Somers, W.G.P. Schouten, K. Frankena, E.N. Noordhuizen-Stassen, and J.H.M. Metz, Risk factors for interdigital dermatitis and heel erosion in dairy cows kept in cubicle houses in The Netherlands, Preventive Veterinary Medicine, 71, 2005b, 24-34.

[13]. Z.E. Barker, J.R. Amory, J.L. Wright, R.W. Blowey, and L.E. Green, Management factors associated with impaired locomotion in dairy cows in England and Wales, Journal of Dairy Science, 9, 2007, 3270-3277.

[14]. E. Yaylak, Y. Akbas, I. Kaya, and C. Uzmay, The effects of several cow and herd level factors on lameness in Holstein cows reared in Izmir province of Turkey, Journal of Animal and Veterinary Advances, 9, 2010, 2714-2722.

[15]. J. DeVries, M.G. Aarnoudse, H.W. Barkema, K.E. Leslie, and M.A.G. von Keyserlingk, Associations of dairy cow behavior, barn hygiene, cow hygiene, and risk of elevated somatic cell count, Journal of Dairy Science, 95, 2012, 5730-5739.

[16]. G. Cramer, K.D. Lis semore, C.L. Guard, K.E. Leslie, and D.F. Kelton, Herd-level risk factors for seven different foot lesions in Ontario Holstein cattle housed in tie stalls or free stalls, Journal of Dairy Science, 92, 2009, 1404-1411.

[17]. K.A. Leach, J.E. Offer, I. Svoboda, and D.N. Logue, Effects of type of forage fed to dairy heifers: associations between claw characteristics, clinical lameness, environment and behavior, Veterinary Journal, 169, 2005, 427-436.

[18]. J. Hultgren, and C. Bergsten, Effects of a rubber-slatted flooring system on cleanliness and foot health in tied dairy cows, Preventive Veterinary Medicine, 52, 2001, 75-89.

[19]. M.A. Magnusson, H. Herlin, and M. Ventorp, Short communication: Effect of Alley Floor Clean liness on Free-Stall and Udder Hygiene, Journal of Dairy Science, 91, 2008, 3927-3930.

[20]. L.D. Warnick, D. Janssen, C.L. Guard, and Y.T. Gröhn, The effect of lameness on milk production in dairy cows, Journal of Dairy Science, 84, 2001, 1988-1997.
[21]. L.E.Green, V.J. Hedges, Y.H. Schukken, R.W. Blowey, and A.J. Packington, The impact of clinical lameness on the milk yield of dairy cows, Journal of Dairy Science, 85, 2002, 2050-2256.

[22]. S.C. Archer, M.J. Green, and J.N. Huxley, Association between milk yield and serial locomotion score assessment in UK dairy cows, Journal of Dairy Science, 93, 2010, 4045-4053.

[23]. H.W. Barkema, J.D. Westrik, K.A.S. van Keulen, Y.H. Schukken, and A. Brand, The effects of lameness on reproductive performance, milk production and culling in Dutch dairy farms, Preventive Veterinary Medicine, 20, 1994, 249-259.

[24]. E.J. Garbarino, J.A. Hernandez, J.K. Shearer, C.A. Risco, and W.W. Thatcher, Effect of lameness on ovarian activity in postpartum Holstein cows, Journal of Dairy Science, 87, 2004, 4123-4131.

[25]. S.L. Walker, R.F. Smith, J.E. Routly, D.N. Jones, M.J. Morris, and H. Dobson, Lameness, activity time-budgets, and estrus expression in dairy cattle, Journal of Dairy Science, 91, 2008, 4552-4559.

[26]. A.H. Sanders, J.K. Shearer, and A. De Vries, Seasonal incidence of lameness and risk factors associated with thin soles, white line disease, ulcers, and sole punctures in dairy cattle, Journal of Dairy Science, 92, 2009, 3165-3174.

[27]. C. Enevoldsen, Y.T. Gröhn, and I. Thysen, Heel erosion and other interdigital disorders in dairy cows: Associations with season, cow characteristics, disease, and production, Journal of Dairy Science, 74, 1991, 1299-1309.

[28]. T. Manske, J. Hultgren, and C. Bergsten, Prevalence and interrelationships of hoof lesions and lameness in Swedish dairy cows, Preventive Veterinary Medicine, 54, 2002, 247-263.

[29]. L.A. Espejo, M.I. Endres, and J.A. Salfer, Prevalence of lameness in high-producing Holstein cows housed in freestall barns in Minnesota, Journal of Dairy Science, 89, 2006, 3052-3058.

[30]. B.H. Nielsen, P.T. Thomsen, and J.T. Sorensen, Identifying risk factors for poor hind limb cleanliness in Danish loosehoused dairy cows, Animal, 5, 2011, 16131619.

[31]. K. Schoepke, S. Weidling, R. Pijl, and H.H. Swalve, Relationships between bovine hoof disorders, body condition traits, and testday yields, Journal of Dairy Science, 96, 2013, 679-689. 
[32]. W. Refaai, M. Van Aert, A.M. Abd El-Aal, A. E. Behery, G. Opsomer, Infectious diseases causing lameness in cattle with a main emphasis on digital dermatitis (Mortellaro disease), Livestock Science, 156, 2013, 53-63.

[33]. J.F. Tarlton, D.E. Holah, K.M. Evans, S. Jones, G.R. Pearson, and A.J.F. Webster, Biomechanical and histopathological changes in the support structures of bovine hooves around the time of first calving, Veterinary Journal, 163, 2002, 196-204.

[34]. M. Holzhauer, C. Hardenberg, C. Bartels, and K. Frankena, Herd- and cow-level prevalence of digital dermatitis in the Netherlands and associated risk factors, Journal of Dairy Science, 89, 2006, 580588. 